DOI: https://doi.org/10.32663

\title{
PENGARUH PEMBERIAN KOMPOSISI PAKAN TEPUNG TONGKOL JAGUNG YANG BERBEDA TERHADAP PERTUMBUHAN IKAN TAWES (Puntius javanicus)
}

\section{(The Influence of The Composition of Dairy Food of Maize Corn Meats on Tawes Fish Growth (Puntius javanicus))}

\author{
Aan Novrianto $^{1}$, Yulfiperius ${ }^{1 *}$, Andriyeni ${ }^{1}$, Asro Nurhabib ${ }^{1}$, Supriyono ${ }^{2}$ \\ ${ }^{1}$ Jurusan Budidaya Perairan, Fakultas Pertanian Universitas Prof.Dr.Hazairin,SH Bengkulu \\ Jl. Jend. Soedirman No. 184 Bengkulu \\ ${ }^{2}$ Jurusan Pendidikan Geografi, FKIP Universitas Prof.Dr.Hazairin,SH Bengkulu \\ Jl. Jend. Ahmad Yani No. 01 Bengkulu \\ *Coresponden Author, Email: f.333ry@gmail.com
}

\begin{abstract}
This research was conducted in April s / d June 2017 located in Fisheries Laboratory of University Prof. Dr. Hazairin, SH Bengkulu. The design of this study used a Completely Randomized Design with 4 Treatments and 6 repeats. The treatments were $(1)=C o r n C o b$ 157 gram, (2) = Corncob 167 gram, (3) = CornCob 177 gram, (4) = Corncob 187 gram. To know the effect or not done an analysis of variance and continued with a test of the Duncan Multiple Range Test (DMRT) 5\% and 1\%. The parameters observed were absolute weight, absolute length, feed conversion, feed efficiency, and fish survival. The results showed that giving different feed composition of corn cob feed was a significant effect on absolute weight growth, absolute length, feed conversion, feed efficiency but no significant effect on survival of Tawes (Puntius javanicus). Absolute weight growth, absolute length, feed conversion, and feed efficiency are best found in Treatment P1 = Corncob 157 grams and survival of Tawes (Puntius javanicus) $100 \%$.
\end{abstract}

Keywords: Corncob, Growth, Tawes (Puntius javanicus)

\section{ABSTRAK}

Penelitian ini dilaksanakan pada bulan April sampai dengan Juni 2017 berlokasi di Laboratorium Perikanan Universitas Prof. Dr. Hazairin, SH Bengkulu. Penelitian ini menggunakan Rancangan Acak Lengkap dengan 4 Perlakuan dan 6 Ulangan. Perlakuan yang di uji adalah Perlakuan (1) = Tongkol Jagung 157 gram, (2) = Tongkol Jagung 167 gram, (3) = Tongkol Jagung 177 gram, (4) = Tongkol Jagung 187 gram. Untuk mengetahui berpengaruh atau tidak dilakukan analisis sidik ragam dan dilanjutkan dengan uji Duncan Multiple Range Test (DMRT) 5\% dan 1\%. Parameter yang di amati adalah berat mutlak, panjang mutlak, konversi pakan, efisiensi pakan dan kelangsungan hidup ikan. Hasil penelitian menunjukkan bahwa pemberian komposisi pakan tepung tongkol jagung yang berbeda berpengaruh sangat nyata terhadap pertumbuhan berat mutlak, panjang mutlak, konversi pakan, efisiensi pakan tetapi tidak berpengaruh nyata terhadap kelangsungan hidup Ikan Tawes (Puntius javanicus). Pertumbuhan berat mutlak, panjang mutlak, konversi pakan dan efisiensi pakan yang terbaik terdapat pada Perlakuan (1) = Tongkol Jagung 157 gram dan kelangsungan hidup Ikan Tawes (Puntius javanicus) $100 \%$.

Kata kunci : ikan Tawes (Puntius javanicus), pertumbuhan, tongkol jagung, 


\section{DOI: https://doi.org/10.32663}

\section{PENDAHULUAN}

Ikan Tawes merupakan salah satu jenis ikan air tawar yang bisa di budidayakan di masyarakat. Ikan Tawes dapat dimanfaatkan sebagai ikan konsumsi, juga dapat meningkatkan nilai gizi masyarakat. Ikan ini memiliki kandungan gizi yaitu protein $13 \%$ dan kandungan asam lemak omega-3 1,5/100 gram, serta memiliki daging yang kenyal dan sedikit lemak (Susanto, 2000). Ikan Tawes dapat di budidayakan secara intensif. Makanan yang diberikan untuk budidaya Ikan Tawes pun cukup mudah didapatkan. Pakan yang diberikan bisa berupa pakan pelet yang sudah banyak dijual dipasaran ataupun Ikan Tawes ini juga bisa diberikan pakan berupa sayur-sayuran yang sudah tidak dimanfaatkan lagi oleh pedagang dipasaran atau daun-daun tanaman seperti daun talas, daun ubi dan lain-lain (Cahyono, 2011).

Tongkol jagung merupakan limbah pertanian yang sangat melimpah dan dapat dimanfaatkan sebagai pakan ikan. Tongkol jagung mengandung serat kasar dan protein kasar yang cukup tinggi terdiri dari bahan kering (BK) sebesar 90\%, Protein (PK) sebesar 11,38\%, Lemak kasar (LK) sebesar 5,39\%, Abu sebesar 8,30\% Serat kasar (SK) sebesar 21,09\% Air sebesar 16,06\% (Yulfiperius 2015) setara kandungan protein dedak padi yaitu sebesar $12,5 \%$, lemak sebesar 1,3\%, serat kasar sebesar $16 \%$, abu sebesar $2,5 \%$ sehingga tepung tongkol jagung dapat dijadikan bahan penyusun ransum pakan ikan sebagai bahan pengganti dedak mengingat dedak padi yang semakin diminati dan harga yang mulai tinggi (NRC 1983/Yulfiperius 2014).

Pengolahan tongkol jagung menjadi pakan dapat dilakukan dengan menggiling tongkol jagung hingga halus menjadi tepung kemudian tepung tongkol yang sudah dicampurkan dengan bahan lainnya dibuat dalam bentuk pelet. Pakan yang berbentuk pelet bertujuan untuk memudahkan pemberian dan penanganan pakan menjadi lebih praktis (Suhartanto et al., 2003). Tongkol jagung dijadikan bahan pakan untuk pembuatan pelet sebelumnya sudah dilakukan yakni pada Ikan Nila dengan kandungan protein sebesar 35\% dan perlakuan tepung tongkol jagung dimulai dari 137 gram, 147 gram, 157 gram, 167 gram, 177 gram dan 187 gram, yang mana perlakuan terbaik terdapat pada perlakuan 177 gram (Rahmadika, 2016). Penelitian bertujuan untuk mengetahui pengaruh pemberian komposisi pakan tepung tongkol jagung yang berbeda terhadap pertumbuhan Ikan Tawes (Puntius javanicus).

\section{BAHAN DAN METODE}

Penelitian ini dilaksanakan selama 60 hari, dimulai pada bulan April sampai bulan Juni 2017 di Laboratorium Perikanan Universitas Prof. Dr. Hazairin, SH Bengkulu. Alat dan bahan yang digunakan, timbangan, unit $\mathrm{pH}$ meter, termometer, $\mathrm{DO}(\mathrm{Mg} / \mathrm{l})$ meter, serokan halus, wadah bak plastik dan bahan yang digunakan adalah bibit Ikan Tawes ukuran $5 \pm 0,5 \mathrm{~cm}$ sebanyak 144 ekor dengan padat per wadah 6 ekor, Tepung tongkol jagung ,Tepung ikan, Minyak jagung ,Premix , CMC. Rancangan penelitian yang digunakan adalah Rancangan Acak Lengkap (RAL) yaitu terdiri dari 4 perlakuan dengan tiaptiap perlakuan di ulang sebanyak 6 kali, sehingga didapat 24 unit perlakuan. Adapun perlakuan pemberian pakan yang digunakan sebagai berikut: Perlakuan (1) :pemberian pakan tepung Tongkol Jagung 157 gram, (2). pemberian pakan tongkol jagung 167 gram, (3). P3 : pemberian pakan Tongkol Jagung 177 gram, (4). P4 : pemberian 


\section{DOI: https://doi.org/10.32663}

pakan Tongkol Jagung 187 gram untuk mengetahui pengaruh pemberian komposisi pakan tepung Tongkol Jagung yang berbeda dilakukan analisis sidik ragam pada taraf $5 \%$ dan $1 \%$, sedangkan untuk mengetahui pakan yang terbaik maka dilakukan uji Duncant Multiple Range Test (DMRT) pada $1 \%$.

Penelitian dilakukan dengan menebar sebanyak 144 ekor dengan ukuran ikan uji $5 \pm 0,5 \mathrm{~cm}$. Sebelum melakukan penebaran berat dan panjang ikan uji terlebih dahulu di ukur. Setelah itu ikan ditebar kedalam masing-masing wadah penelitian dengan padat tebar 6 ekor/wadah. Ikan uji di beri pakan pelet yang dibuat sendiri diberikan 3 kali sehari dengan dosis $5 \%$ dari berat biomassa ikan uji. Pengukuran berat dan panjang di lakukan di awal penebaran selanjutnya pengukuran dilakukan setiap 15 hari sekali selama penelitian 60 hari. Pengamatan kualitas air yang diukur yaitu derajat keasaman $(\mathrm{pH})$ air, suhu dan oksigen terlarut. Pengukuran dilakukan pada awal, tengah, dan akhir penelitian. Parameter yang diamaati pada penelitian ini antara lain pengamatan panjang dan berat ikan, konversi pakan, efisiensi pakan, kelangsungan hidup dan kualitas air. Pada parameter kualitas air pengamatan dilakukan pada $\mathrm{pH}$, suhu dan DO

\section{HASIL DAN PEMBAHASAN}

Setelah melakukan penelitian mengenai pengaruh pemberian komposisi pakan tepung tongkol jagung yang berbeda terhadap pertumbuhan Ikan Tawes hasilnya dapat dilihat dari Gambar 1.

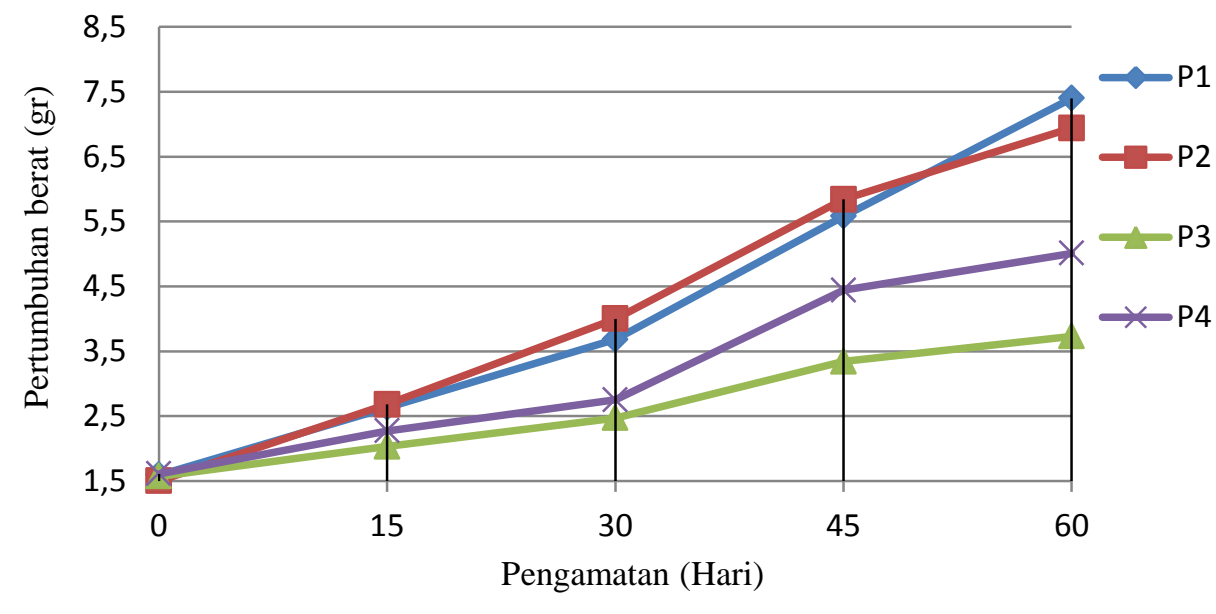

Gambar 1. Grafik pertumbuhan berat ikan tawes

Berdasarkan Gambar 1 terlihat bahwa grafik pertumbuhan berat ikan naik secara bertahap. Saat awal penelitian pertumbuhan berat Ikan Tawes hari (0) sampai hari (15) terlihat lambat yang disebabkan karena kondisi ikan yang mengalami fase adaptasi dan membutuhkan banyak energi. Kegiatan adaptasi membutuhkan banyak energi dari pakan yang diserap sehingga energi dari pakan untuk pertumbuhan berkurang dan membuat pertumbuhan berat ikan menjadi lambat. Pada hari (30) sampai hari (60) pertumbuhan berat ikan terlihat cepat ini 


\section{DOI: https://doi.org/10.32663}

disebabkan ikan sudah mulai bisa beradaptasi dengan lingkungan yang baru sehingga energi dari pakan dapat di serap dan di manfaatkan dengan baik untuk pertumbuhan berat Ikan Tawes.

Rata-rata pertumbuhan berat Ikan Tawes (Puntius javanicus) selama penelitian yang tertinggi terdapat pada Perlakuan (1) (Tepung tongkol 157 gram), Perlakuan (2) (Tepung tongkol 167 gram), Perlakuan (3) (Tepung tongkol 177 gram) dan Perlakuan (4) (Tepung tongkol 187 gram). Setelah dilakukan perhitungan berat Ikan Tawes seperti Gambar 1 perlakuan (1) menunjukkan pertumbuhan berat ikan selama penelitian sangat baik sedangkan perlakuan (3) pertumbuhan berat pada Ikan Tawes sangat lambat. Pertumbuhan menurut Effendie (1978) pertumbuhan berat pada setiap ikan tumbuh dalam jangka waktu tertentu. Kecepatan pertumbuhan ikan beraneka ragam hal ini di sebabkan adanya perbedaan jumlah makanan yang dimakan, kemampuan mencerna dan menyerap makanan dari setiap ikan berbeda-beda. Menurut Mudjiman (2009) ikan akan mengalami pertumbuhan dengan baik apabila pakan yang dimakan oleh ikan dapat dimanfaatkan dengan baik.

Pemberian pakan tepung tongkol jagung yang berbeda berpengaruh sangat nyata terhadap pertumbuhan berat Ikan Tawes (Puntius javanicus). Berat rata-rata yang paling tinggi yaitu Perlakuan (1) dan merupakan perlakuan terbaik untuk pertumbuhan berat Ikan Tawes (Puntius javanicus). Kemudian pada perlakuan (2) dari konversi pakan berselisih sedikit ini perkembanganya dan pertumbuhan ikan cukup baik tetapi konversi pakan yang menyebabkan tidak idelanya. Sedangkan pada perlakuan (3) dan (4) perkembanganya dipengaruhi oleh konsentrasi pakan pada air cukup banyak sehingga ada indikasi ikan tidak banyak mencerna dalam pertumbuhanya. Sehingga perkembangan awal pertumbuhan ikan ideal pada perlakuan (1) yaitu dengan formulasi pakan ikan tepung Tongkol Jagung 157 gram pertumbuhan berat ikan 34,77gr (Tabel 1).

Tabel 1. Hasil uji dmrt pertumbuhan berat mutlak ikan Tawes (Puntius javanicus)

\begin{tabular}{ccc}
\hline Perlakuan & Rata-rata berat ikan $(\mathrm{g})$ & DMRT 1\% \\
\hline$(3)$ & 12,97 & $\mathrm{a}$ \\
\hline$(4)$ & 20,40 & $\mathrm{~b}$ \\
\hline$(2)$ & 32,60 & $\mathrm{c}$ \\
\hline$(1)$ & 34,77 & $\mathrm{c}$ \\
\hline
\end{tabular}

Keterangan :-huruf yang notasinya sama tidak berbeda nyata dan huruf yang notasinya berbeda berarti berbeda nyata.

\section{Pertumbuhan Panjang Mutlak}

Grafik pertumbuhan panjang Ikan Tawes selama penelitian hari (0) sampai hari (60) menunjukkan pertumbuhan panjang naik secara bertahap. Perlakuan (1) menunjukkan pertumbuhan panjang ikan sangat baik sedangkan perlakuan (3) pertumbuhan panjang ikan sangat lambat (Gambar 2). Perbedaan pertumbuhan panjang ikan masing-masing perlakuan disebabkan karena setiap ikan mempunyai kemampuan menyerap dan mencerna pakan yang diberikan berbeda-beda. Pakan yang di berikan oleh ikan ikut berpengaruhi dalam pertumbuhan yang pada dasarnya pertumbuhan setiap ikan akan tercapai secara baik jika ikan tersebut dapat memakan pakan yang diberikan dan 


\section{DOI: $\underline{\text { https://doi.org/10.32663 }}$}

dimanfaatkan ikan secara maksimal untuk pertumbuhan. Hal ini sesuai dengan Rufiati (2009) bahwa apabila pakan yang diberikan dapat dimanfaatkan dengan maksimal oleh ikan maka pertumbuhan panjang maupun berat ikan akan ikut berpengaruh.

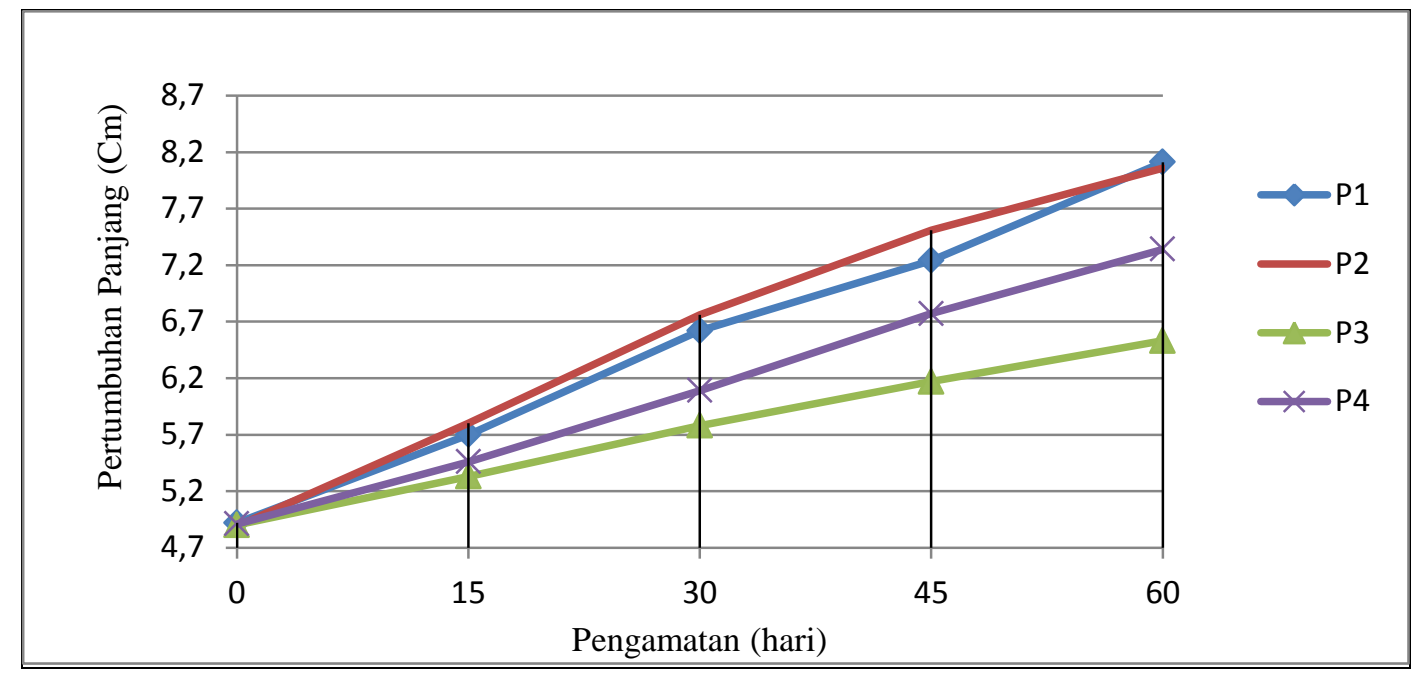

Gambar 2. Grafik pertumbuhan panjang ikan tawes

Pemberian pakan tongkol jagung yang tinggi yaitu Perlakuan (1) $(19,13 \mathrm{~cm})$ dan berbeda berpengaruh sangat nyata terhadap merupakan perlakuan terbaik untuk pertumbuhan berat ikan Tawes (Puntius pertumbuhan panjang Ikan Tawes (Puntius javanicus. Panjang rata-rata yang paling javanicus) (Tabel 2).

Tabel 2. Hasil uji DMRT pertumbuhan panjang ikan Tawes (Puntius javanicus)

\begin{tabular}{ccc}
\hline Perlakuan & Rata-rata panjang ikan (gr) & DMRT 1\% \\
\hline$(3)$ & 9,77 & $\mathrm{a}$ \\
\hline$(4)$ & 14,63 & $\mathrm{~b}$ \\
\hline$(2)$ & 19,02 & $\mathrm{c}$ \\
\hline$(1)$ & 19,13 & $\mathrm{c}$
\end{tabular}

Keterangan :- Huruf yang notasi sama tidak berbeda nyata dan huruf yang notasinya berbeda berarti berbeda nyata.

\section{Konversi Pakan}

Pemberian pakan tepung tongkol jagung yang berbeda berpengaruh sangat nyata terhadap konversi pakan pada ikan Tawes (Puntius javanicus. Nilai rata-rata konversi dapat diketahui bahwa perlakuan yang terbaik yaitu Perlakuan (1) dengan nilai rata-rata konversi terkecil dengan nilai 1,75 (Tabel 3).
Konversi pakan artinya jumlah berat pakan yang diubah menjadi $1 \mathrm{~kg}$ daging (Yulfiperius, 2011). Pengaruh terhadap konversi pakan dapat terjadi apabila pakan yang diberikan dapat dimakan oleh ikan secara keseluruhan dan tidak menyisakan pakan jika pakan yang diberikan masih tersisa maka akan berpengaruh pada 


\section{DOI: https://doi.org/10.32663}

konversi pakan. Nilai konversi pakan digunakan kurang baik dan sebaliknya jika digunakan juga untuk mengetahui kualitas nilai konversi semakin kecil maka kualitas pakan yang diberikan pada ikan, bila nilai pakan yang digunakan semakin baik. konversi tinggi maka kualitas pakan yang (Djajawaseka 1985).

Tabel 3. Hasil uji dmrt pada konversi ikan Tawes (Puntius javanicus)

\begin{tabular}{ccc}
\hline Perlakuan & Rata-rata konversi pakan & DMRT 1\% \\
\hline$(1)$ & 1,75 & $\mathrm{a}$ \\
\hline$(2)$ & 1,98 & $\mathrm{a}$ \\
\hline$(4)$ & 2,50 & $\mathrm{bc}$ \\
\hline$(3)$ & 3,30 & $\mathrm{~cd}$
\end{tabular}

Keterangan :- huruf yang notasinya sama tidak berbeda nyata dan huruf yang notasinya berbeda berarti berbeda nyata.

\section{Efisiensi Pakan}

Pemberian pakan tepung tongkol jagung yang berbeda berpengaruh sangat nyata terhadap efisiensi pakan ikan Tawes (Puntius javanicus). Perlakuan (1) merupakan perlakuan terbaik untuk efisiensi pakan ikan Tawes (Puntius javanicus) (Tabel 4). Nilai efisiensi dan konversi digunakan untuk melihat kualitas pakan yang diberikan pada ikan. Nilai
Efisiensi pakan semakin tinggi maka kualitas pakan juga semakin baik, sebaliknya bila nilai efisiensi pakan semakin rendah maka kualitas pakan juga semakin rendah. Bila pakan yang diberikan dimakan oleh ikan tanpa ada sisa maka pertumbuhan ikan pun ikut meningkat secara maksimal ( Anonimus 1993, dalam Rohina 2005).

Tabel 4. Hasil uji DMRT pada efisiensi pakan ikan Tawes (Puntius javanicus)

\begin{tabular}{ccc}
\hline Perlakuan & Rata-Rata Efisiensi pakan & DMRT $1 \%$ \\
\hline$(3)$ & 30,73 & $\mathrm{a}$ \\
\hline$(4)$ & 41,18 & $\mathrm{~b}$ \\
\hline$(2)$ & 51,54 & $\mathrm{c}$ \\
\hline$(1)$ & 57,34 & $\mathrm{c}$
\end{tabular}

Keterangan :- Huruf yang notasinya sama tidak berbeda nyata dan huruf yang notasinya berbeda berarti berbeda nyata.

\section{Kelangsungan Hidup (SR)}

Tingkat kelulusan atau kelangsungan hidup selama pengamatan 60 hari dapat diketahui tingkat kelangsungan hidup Ikan Tawes (Puntius javanicus) selama penelitian yakni $100 \%$ dari setiap perlakuan, maka tidak perlu dilakukan uji lanjut. Apabila ikan dapat dipelihara dengan baik dan tanpa adanya gangguan serta pakan yang diberikan cukup maka kelangsungan hidup ikan akan tinggi hal ini sesuai pendapat Soetomo (2000) dalam Werna (2008), bila ikan yang dipelihara dengan baik, terpenuhi semua kebutuhan dan tidak adanya gangguan maka 


\section{DOI: $\underline{\text { https://doi.org/10.32663 }}$}

kelangsungan hidup ikan dapat mencapai $100 \%$.

\section{Kualitas Air}

Pengamatan kualitas air dilakukan tiga kali selama penelitian berlangsung, yaitu pada awal, tengah, dan akhir pemeliharan pengamatan berupa Suhu, Disolved oksigen (DO), dan pH (Tabel 5).

Tabel 5. Kisaran pengukuran kualitas air

\begin{tabular}{|c|c|c|c|c|}
\hline \multirow[t]{2}{*}{ Perlakuan } & \multirow[t]{2}{*}{ Parameter } & \multicolumn{3}{|c|}{ Pengamatan } \\
\hline & & Awal & Tengah & Akhir \\
\hline \multirow[t]{3}{*}{ (1) } & Suhu & $27-29^{\circ} \mathrm{C}$ & $27-29^{\circ} \mathrm{C}$ & $27-29^{\circ} \mathrm{C}$ \\
\hline & $\mathrm{O}^{2}$ & 5-6 ppm & 5-6 ppm & 5-6 ppm \\
\hline & $\mathrm{pH}$ & $7-7,6$ & $7-7,6$ & $7-7,6$ \\
\hline \multirow[t]{3}{*}{ (2) } & Suhu & $27-29$ & $27-29$ & $27-29$ \\
\hline & $\mathrm{O}^{2}$ & 5-6 ppm & 5-6 ppm & 5-6 ppm \\
\hline & $\mathrm{pH}$ & $7-7,6$ & $7-7,6$ & $7-7,6$ \\
\hline \multirow[t]{3}{*}{ (3) } & Suhu & $27-29^{\circ} \mathrm{C}$ & $27-29^{\circ} \mathrm{C}$ & $27-29^{\circ} \mathrm{C}$ \\
\hline & $\mathrm{O}^{2}$ & 5-6 ppm & 5-6 ppm & 5-6 ppm \\
\hline & $\mathrm{pH}$ & $7-7,6$ & $7-7,6$ & $7-7,6$ \\
\hline \multirow[t]{3}{*}{ (4) } & Suhu & $27-29^{\circ} \mathrm{C}$ & $27-29^{\circ} \mathrm{C}$ & $27-29^{\circ} \mathrm{C}$ \\
\hline & $\mathrm{O}^{2}$ & 5-6 ppm & 5-6 ppm & 5-6 ppm \\
\hline & $\mathrm{pH}$ & $7-7,6$ & $7-7,6$ & $7-7,6$ \\
\hline
\end{tabular}

Tabel 5 memperlihatkan bahwa kualitas air selama pemeliharan cukup baik untuk pertumbuhan Ikan Tawes (Puntius javanicus). Menurut Susanto dan Sarto (2005) bahwa Ikan Tawes hidup di habitat dengan kisaran suhu ideal $20^{\circ}-33^{\circ} \mathrm{C}$. Suhu pada saat penelitian berkisar $27^{\circ}-29^{\circ} \mathrm{C}$ sehingga suhu sudah termasuk kriteria suhu yang baik untuk pertumbuhan tawes. Air yang digunakan harus dijaga kualitas airnya dengan cara air yang ada didalam wadah disipon dan pada saat penggantian air sebaiknya tidak dilakukan secara total karena akan membuat ikan stres.

Derajat keasaman atau $\mathrm{pH}$ selama penelitian berkisar antara 7-7,6 dan DO berkisar antara 5-6 ppm. Menurut Irawan (2004) bahwa pemeliharaan ikan yang baik dilakukan pada air yang mempunyai $\mathrm{pH}$ kisaran 7-8,5 yang merupakan kisaran umum $\mathrm{pH}$ air tawar, dan DO 5-10 ppm. Dengan demikian $\mathrm{pH}$ maupun DO (oksigen terlarut) yang selama penelitian ini memenuhi syarat untuk pemeliharaan Ikan Tawes. Karena apabila pH dan oksigen terlarut rendah akan mengakibatkan ikan akan mengalami kurangnya nafsu makan dan mudah terserang penyakit.

\section{KESIMPULAN DAN SARAN}

Pemberian tepung tongkol jagung berpengaruh sangat nyata terhadap pertumbuhan berat mutlak, panjang mutlak, konversi pakan dan efesiensi pakan ikan Tawes (Puntius javanicus), tetapi tidak berpengaruh nyata terhadap kelangsungan hidup ikan. Perlakuan terbaik yakni tepung tongkol jagung $157 \mathrm{~g}$ dengan nilai rata-rata pertumbuhan berat mutlak Ikan Tawes (Puntius javanicus) sebesar 34,77 g, 
DOI: https://doi.org/10.32663

pertumbuhan panjang mutlak sebesar 19,13 $\mathrm{cm}$, dengan konversi pakan sebesar 1,75 dan efesiensi pakan sebesar 57,34 serta kelangsungan hidup Ikan Tawes (Puntius javanicus) sebesar $100 \%$.

Untuk pemeliharaan Ikan Tawes (Puntius javanicus) disarankan kisaran pemberian pakan sebaiknya menggunakan tepung tongkol jagung 157-167 gram. Sehingga akan memberikan pengaruh yang baik pada perkembangan dan pertumbuhan panjang berat ikan. Formulasi ini perlakuanya hanya pada ikan Ikan Tawes (Puntius javanicus), sehingga untuk jenis ikan yang lain perlunya ada kajian lanjutan dan memeberikan keberlajutan akan penelitian ini.

\section{DAFTAR PUSTAKA}

Cahyono, B. 2011. Untung Berlipat Budidaya Tawes Sebagai Bahan Baku Keripik. Lili Publisher. Yogyakarta

Djajasewaka, H.Y. 1985. Makanan Ikan. Penerbit : Penebar Swadaya, Jakarta.

Efendi R. 1978. Biologi perikanan. Yayasan Dwi Sri. Bogor.

Hanafiah .A. K. 2010. Rancangan Percobaan. Fakultas Pertanian Sriwijaya Palembang. Rajawali per. Edisi Ketiga.

Irawan, dkk. 2004. Faktor-faktor Penting Dalam Pembesaran Ikan Di Fasilitasi Nursly dan Pembesaran. Institut Pertanian Bogor.

Mudjiman, A 2000, Makanan Ikan : Penebar Swadaya. Jakarta

Mudjiman, A 2009. Makanan Ikan : Penebar Swadaya. Cet 22. Jakarta

Rio Rahmadika, 2016. Pemberian Tepung Tongkol Jagung Yang Berbeda Untuk Pertumbuhan Ikan Nila (Oreochromis niloticus). Skripsi Fakultas Pertanian
Program Studi Budidaya Perairan Unihaz, tidak dipublikasikan

Rohina, 2005. Pengaruh Padat Tebar Yang Berbeda Terhadap Pertumbuhan Ikan Tawes (Puntius javanicus) Di Jaring Apung. Skripsi Fakultas Pertanian Program Studi Budidaya Perairan

Rufiati, Indah. 2008. Laporan Pratikum Manajemen Akuakultur Tawar. Universitas Gajah Mada. Yogyakarta Susanto, 2000. Usaha Pembenihan dan Pembesaran Tawes. Jakarta: Penebar

Swadaya Susanto, B. dan Sarto, T. 2005. Petunjuk Praktis Budidaya Ikan Tawes. Kanasius. Yogyakarta

Yulfiperius. 2011. Nutrisi Ikan I. Agroqua Press

Yulfiperius. 2014. Nutrisi ikan. PT Raja Grafindo Persada, Depok.

Werna Andiyanto, Tri . 2008. Pengaruh Pemberian Cacing Tanah (Lumbricus rubellus) Dengan Dosis Yang Berbeda Pada Ikan Oskar (Astronotus ocellatus). Sekolah Tinggi Ilmu Perikanan Kalinyamat 